\title{
Integrated Nutrient Management for Lowland Rice (Oryza sativa L.) in the Anuradhapura District of Sri Lanka
}

\author{
D.M.D. Dissanayake* , K.P. Premaratne ${ }^{1}$ and U.R. Sangakkara ${ }^{1}$ \\ Postgraduate Institute of Agriculture \\ University of Peradeniya \\ Sri Lanka
}

\begin{abstract}
The impact of integration of inorganic fertilizer and organic manures on yield of rice (Oryza sativa L.) was evaluated under field conditions over two seasons. The experiment was laid out in a split-plot design with three replicates. The main plots were two rice varieties namely, Kaluheenati and Bg 352, and the sub-plots consisted of five fertilizer/manure combinations viz. T1 - control (without fertilizer and organic manure), $T 2-100 \%$ of fertilizer recommendation of the Department of Agriculture (DOA), T3 - 50\% of fertilizer recommendation of the DOA, T4 - organic manure alone, T5 - 50\% of fertilizer recommendation of the DOA $+T 4$. The variety effect, fertilizer/manure combination effect and interaction effect of variety and fertilizer/manure combination on yield were significant $(p<0.05)$. In Kaluheenati, organic manure (T4) was the most suitable for higher yield. The variety Bg 352 responded positively to organic manures in combination with inorganic fertilizers, which illustrates the possibility of substituting a part of inorganic fertilizers with organic manures (T5) saving 130, 43 and $37 \mathrm{~kg}$ urea, Triple Super Phosphate and Muriate of Potash/ha, respectively.
\end{abstract}

Keywords: Inorganic fertilizer, integrated nutrient management, organic manures, rice varieties

\section{INTRODUCTION}

The use of inorganic fertilizer in rice cultivations of Sri Lanka has been progressively increasing since its introduction. Fertilizer use in paddy cultivation increased from 149,700 to 292,600 tonnes during the period of 1999-2008 (Misra, 2011). The state expenditure on the fertilizer subsidy program in 2009 was Rs. 26.935 billion, which was about $2.24 \%$ of total government expenditure (Weerahewa et al., 2010). However, available reports indicate that the repeated use of inorganic fertilizer alone fails to sustain desired yield, impairs soil physical conditions and reduces organic matter contents (Mohammad, 2010) leads to environmental pollution especially due to their continuous use (Bhakiyathu, 2005).

Expenditure for inorganic fertilizer is high and thus, identifying appropriate and economically feasible approaches, which are environmentally friendly and healthy, is imperative. Integrated nutrient management seems to be a suitable approach to achieve these goals. The drawbacks associated with inorganic sources of plant nutrients are often overcome when they are used in judicious combinations with organic manures. When used in combination, interactions occur and the yield increase is always more than that from the use of equivalent quantities of these nutrient sources alone (Wickramasinghe \& Wijewardena, 2003). Hence, this study investigated the effect of integrating rice straw, green manure (Gliricidia sepium leaves) and Eppawala rock phosphate (ERP) and a Gliricidia leaf extract with inorganic fertilizers on yield of traditional (Kaluheenati) and new-improved (Bg 352) rice varieties in the Anuradhapura district of Sri Lanka.

\section{MATERIALS AND METHODS}

\footnotetext{
1 Department of Crop Science, Faculty of Agriculture, University of Peradeniya, Sri Lanka

Corresponding author: dharmasirid@gmail.com
} 
The experiment was conducted in the rice fields of the Faculty of Agriculture, Rajarata University of Sri Lanka at Puliyankulama in the Anuradhapura district covering two major cropping seasons namely, 2010/2011 Maha [wet season (WS)] and 2011 Yala [dry season (DS)]. The selected site was a conventional rice field, which was left fallowed over the previous four consecutive seasons. The soil of the experiment site belonged to the great soil group Low Humic Glay (LHG) (Order - Alfisols, Sub order Aqualfs, Great group - Tropaqualfs) (Panabokke, 1996). The soil was clay loam in terms of texture with high clay and silt contents (Duminda et al., 2010). The mean seasonal temperatures were $29 \pm 0.34{ }^{\circ} \mathrm{C}$ and $26 \pm 1{ }^{\circ} \mathrm{C}$ for DS and WS, respectively, with an average maximum temperature of $33.5 \pm 0.4{ }^{\circ} \mathrm{C}$ in DS and $30 \pm 1.2^{\circ} \mathrm{C}$ in WS. The quantity of rainfall received in DS and WS of this study were $38 \mathrm{~mm}$ and 1506 $\mathrm{mm}$, respectively.

\section{Crop establishment and management}

Land was prepared by impounding water for two weeks after ploughing and harrowing followed by fine levelling with the help of a wooden leveller. Pre-germinated seeds were broadcast sown at a rate of 137.5 $\mathrm{kg} / \mathrm{ha}$ on the puddled and levelled field.

\section{Experimental design and treatments}

The experiment was laid out in a split plot design with three replicates. The main plots were the two rice varieties, i.e. Kaluheenati and $\mathrm{Bg} 352$ and five fertilizer combinations were used as subplots. The main and sub plot sizes were $20 \mathrm{~m} \times 5 \mathrm{~m}$ and $4 \mathrm{~m} \times 5 \mathrm{~m}$, respectively. Plots were separated by two bunds $(45 \mathrm{~cm}$ width and $30 \mathrm{~cm}$ height), with a drainage canal in between the two bunds to avoid cross contaminations of added fertilizers and manures. The subplot treatments were $\mathrm{T}_{1}$ : The control (without inorganic fertilizer and organic manure), $\mathrm{T}_{2}$ : NPK as inorganic fertilizer at levels recommended by the Department of Agriculture for $3 \frac{1}{2}$ month rice varieties (100\% DOA), $\mathrm{T}_{3}: 50 \%$ of DOA recommendation, $\mathrm{T}_{4}$ : Organic manure alone [ $4 \mathrm{t} / \mathrm{ha}$ air-dried Rice straw $+6 \mathrm{t} / \mathrm{ha}$ Gliricidia leaves $+350 \mathrm{~kg} / \mathrm{ha}$ Eppawala Rock Phosphate $(\mathrm{ERP})+600$ litres/ha Gliricidia leaf extract (applied fortnightly)], and $\mathrm{T}_{5}$ : INM (50\% of DOA $\left.+\mathrm{T}_{4}\right)$.

Rice straw and Gliricidia leaves and ERP $\left(28 \% \mathrm{P}_{2} \mathrm{O}_{5}\right)$ were incorporated after the first ploughing at two weeks before sowing as per treatments. The Gliricidia leaf extract was prepared by fermentation of $20 \mathrm{~kg}$ Gliricidia leaves in 150 litres of water. The extract was applied at a rate of 600 litres/ha, four times at fortnightly intervals over the vegetative period of the rice crop. The inorganic fertilizer was applied at a rate of $120-40-40 \mathrm{~kg}$ of N, $\mathrm{P}_{2} \mathrm{O}_{5}$ and $\mathrm{K}_{2} \mathrm{O} /$ ha respectively, as recommended by the Department of Agriculture. All other management practices were done according to the recommendation of the Department of Agriculture, Sri Lanka (DOA, 2007).

\section{Observation and measurements}

Number of panicles $/ \mathrm{m}^{2}$ was counted at harvest using a $1 \mathrm{~m} \times 1 \mathrm{~m}$ quadrat. The total number of spikelets and filled spikelets/panicle were determined at harvest by taking 30 random panicles from each plot. Grain and straw yields were obtained excluding the $45 \mathrm{~cm}$ borders in each sub plot. The final weight of grain and straw yield were measured after air drying and grain yield was corrected to $14 \%$ moisture content. The harvest index (HI) was obtained from the ratio of grain yield to the grain + straw yield of each plot and expressed as a percentage.

The data were statistically analyzed to determine the significant difference of treatments. Analysis of variance was done using GLM (General Linear Model) procedure and means were separated using Least Square method (LS means).

\section{RESULTS AND DISCUSSION}

The interaction effects of variety and fertilizer/manure combinations on yield and harvest index (HI) were significant $(\mathrm{p}<0.05)$. The grain yield and $\mathrm{HI}$ of $\mathrm{Bg} 352$ was significantly higher than that of Kaluheenati 
(Table 1). The productivity of rice plant is greatly dependent on the panicles $/ \mathrm{m}^{2}$, percentage of filled spikelets/panicle and 1000 seed weight (Siavoshi et al., 2011). In the present investigation, a significantly higher number of panicles $/ \mathrm{m}^{2}$ and filled spikelets/panicle, and thousand seed weight were observed in $\mathrm{Bg}$ 352 compared to those in Kaluheenati. This variation is due to the genetic characteristics of varieties and these may be the reasons for higher yield in $\mathrm{Bg} 352$.

The seasonal effect on yield was significant $(\mathrm{p}<0.05)$ while it was not significant $(\mathrm{p}>0.05)$ in HI. The grain yield during DS (4.82 t/ha) was higher than that obtained during WS (3.64 t/ha) (Table 1). Higher productivity during the DS could be attributed to the higher amount of solar radiation received during the DS (Venkatewaralu \& Vispears, 1987).

In both seasons, Kaluheenati (traditional variety) with $100 \%$ DOA $\left(\mathrm{T}_{2}\right)$ recorded a lower grain yield than in other fertilizer/manure combinations showing low response for applied inorganic fertilizers. The impact of organic manure alone $\left(\mathrm{T}_{4}\right)$ and $50 \%$ DOA $\left(\mathrm{T}_{3}\right)$ on grain yield was similar in both seasons. In contrast, Bg 352 (new-improved variety) performed differently due to its higher fertilizer responsiveness. Although, the highest yield was recorded in INM-treated plots $\left(\mathrm{T}_{5}\right)$, a similar yield was observed in 100\% DOA $\left(\mathrm{T}_{2}\right)$ in both seasons. There were no differences in yields with organic manure alone $\left(\mathrm{T}_{4}\right)$ and $50 \% \mathrm{DOA}\left(\mathrm{T}_{3}\right)$ in both seasons.

The HI of Kaluheenati in100\% DOA $\left(\mathrm{T}_{2}\right)$ was significantly lower $(\mathrm{p}<0.05)$ than that of organic manure alone $\left(\mathrm{T}_{4}\right)$ in both seasons. Impact of fertilizer/manure combination on $\mathrm{HI}$ of $\mathrm{Bg} 352$ was not significant $(p>0.05)$ in WS, but was significant in DS. The variety Bg 352 recorded the highest HI in INM $\left(\mathrm{T}_{5}\right)$ and it was statistically similar to those of $100 \%$ DOA $\left(\mathrm{T}_{2}\right)$ control $\left(\mathrm{T}_{1}\right)$ in DS.

Table 1. Effect of fertilizer/manure combinations on yield and harvest index of variety Kaluheenati and Bg 352

\begin{tabular}{|c|c|c|c|c|c|}
\hline \multirow{2}{*}{ Variety } & \multirow[t]{2}{*}{ Treatment } & \multicolumn{2}{|c|}{ Maha 2010/2011 (WS) } & \multicolumn{2}{|c|}{ Yala 2011 (DS) } \\
\hline & & GYD, t/ha & HI, $\%$ & GYD, t/ha & HI, \% \\
\hline \multirow{7}{*}{$\mathrm{V}_{1}$} & $\mathrm{~T}_{1}$ & $2.02 \mathrm{a}$ & $37.0 \mathrm{a}$ & $3.62 \mathrm{a}$ & $40.6 \mathrm{bc}$ \\
\hline & $\mathrm{T}_{2}$ & $3.18 \mathrm{~b}$ & $35.9 \mathrm{a}$ & $4.15 \mathrm{ab}$ & $34.8 \mathrm{a}$ \\
\hline & $\mathrm{T}_{3}$ & $3.57 \mathrm{c}$ & $40.4 \mathrm{bc}$ & $4.34 \mathrm{~b}$ & $42.1 \mathrm{c}$ \\
\hline & $\mathrm{T}_{4}$ & $3.44 \mathrm{bc}$ & $41.06 \mathrm{c}$ & $4.41 \mathrm{~b}$ & $42.8 \mathrm{c}$ \\
\hline & $\mathrm{T}_{5}$ & $3.72 \mathrm{c}$ & $39.2 \mathrm{~b}$ & $4.60 \mathrm{~b}$ & $36.6 \mathrm{ab}$ \\
\hline & Root MSE & 0.19 & 2.1 & 0.32 & 2.7 \\
\hline & $\mathrm{CV} \%$ & 6.23 & 2.1 & 7.75 & 6.9 \\
\hline \multirow{7}{*}{$\mathrm{V}_{2}$} & $\mathrm{~T}_{1}$ & $2.57 \mathrm{a}$ & $41.1 \mathrm{a}$ & $4.5 \mathrm{a}$ & $46.3 \mathrm{~b}$ \\
\hline & $\mathrm{T}_{2}$ & $5.10 \mathrm{c}$ & $44.6 \mathrm{a}$ & $6.09 \mathrm{c}$ & $46.5 \mathrm{~b}$ \\
\hline & $\mathrm{T}_{3}$ & $3.86 \mathrm{~b}$ & $43.7 \mathrm{a}$ & $5.19 \mathrm{~b}$ & $42.4 \mathrm{a}$ \\
\hline & $\mathrm{T}_{4}$ & $3.61 \mathrm{~b}$ & $42.5 \mathrm{a}$ & $4.89 \mathrm{~b}$ & $43.6 \mathrm{a}$ \\
\hline & $\mathrm{T}_{5}$ & $5.32 \mathrm{c}$ & $45.2 \mathrm{a}$ & $6.33 c$ & $46.7 \mathrm{~b}$ \\
\hline & Root MSE & 0.23 & 1.5 & 0.24 & 1.5 \\
\hline & $\mathrm{CV} \%$ & 5.61 & 3.5 & 4.49 & 2.9 \\
\hline
\end{tabular}

$\mathrm{V}_{1}-$ Kaluheenati, $\mathrm{V}_{2}-\mathrm{Bg} 352, \mathrm{GYD}$ - grain yield at $14 \%$ moisture, $\mathrm{HI}$ - Harvest Index 
Generally, the yield of INM $\left(\mathrm{T}_{5}\right)$ was higher than in the other treatments irrespective of season and variety. The high yield of INM $\left(\mathrm{T}_{5}\right)$ was due to green manures and rice straw, which improves nutrient availability and retention (Hasanuzzaman et al., 2010; Mandal et al., 2004).

The low yield observed in plots treated with $100 \%$ DOA $\left(\mathrm{T}_{2}\right)$ in Kaluheenati was attributable to severe lodging at early reproductive growth stages due to higher plant height boosted by inorganic fertilizers, resulting in a lower HI. The yield reduction was also caused by the reduction of filled spikelet percentage (Siavoshi et al., 2011). A yield reduction was also evident by the lower correlation coefficients between filled spikelet percentage and grain yield. Lower yield of $\mathrm{Bg} 352$ in $100 \% \mathrm{DOA}\left(\mathrm{T}_{2}\right)$ than that of INM $\left(\mathrm{T}_{5}\right)$ was a special observation made in this study, which might be due to additional supply of micronutrients by the applied organic manures.

Organic manure alone $\left(\mathrm{T}_{4}\right)$ produced a significantly lower $(\mathrm{p}<0.05)$ yield of $\mathrm{Bg} 352$ than that with $100 \%$ DOA $\left(\mathrm{T}_{2}\right)$. This might be due to the fact that new-improved varieties were bred for high fertilizer response and when the nutrients supply is inadequate, a significant yield reduction may be possible.

There was a general trend of similar yields in 50\% DOA $\left(\mathrm{T}_{3}\right)$ and organic manure alone $\left(\mathrm{T}_{4}\right)$. This observation confirmed that $50 \%$ of inorganic fertilizer can be substituted by above combination of organic manures.

\section{CONCLUSION}

The suitable fertilizers/manure combination for Kaluheenati was organic manure alone. The new-improved variety $\mathrm{Bg} 352$ produced similar yields in INM $\left(\mathrm{T}_{5}\right)$ and $100 \%$ DOA $\left(\mathrm{T}_{2}\right)$ in both seasons. Positive responses of to INM $\left(T_{5}\right)$ illustrates the possibility of substituting part of inorganic fertilizers with organic manures such as straw and Gliricidia leaves, rock phosphate and Gliricidia leaf extract, thereby saving 130, 43 and $37 \mathrm{~kg}$ Urea, TSP, MOP/ha respectively. As a result $50 \%$ of the expenditure on imported inorganic fertilizer can be saved.

\section{ACKNOWLEDGEMENTS}

Gratitude is expressed to the Faculty of Agriculture, Rajarata University of Sri Lanka for providing the field and other facilities to conduct this research and UGC for providing funds required for research work.

\section{REFERENCES}

Bhakiyathu, B.S. Krihnakumar, S. and Natarajan, S.K. (2005). Response to rice crop to organic manuring in high pH soil. Asian Journal of Plant Sciences. 4, 5, 524-526.

DOA (2007). Sri Lanka rice knowledge bank. [On line]. [Accessed on 02.02.2009]. Available at http://www.knowledgebank.irri.org/sriLanka/index.html.

Duminda, D.M.S. Amarasekara, M.G.T.S. Jinadasa, D.M. Karunrathne, K.N and Vidyarathne, D.D. (2010). Characterization of physical and chemical properties along an undulating reddish brown earth and low humic gley soils at Puliyankulama, Anuradhapura. Proceeding of RUSL-Research Symposium 2010. 2-5.

Hasanuzzaman, M. Ahamed, K.U. Rahmatullah, N.M. Akhter, N. Nahar, K. and. Rahman, M.L. (2010). Plant growth characters and productivity of wetland rice (Oryza sativa L.) as affected by application of different manures. Emir. J. Food Agric. 22,1, 46-58.

Mandal, K.G. Misra, A.K. Hati, K.M. Bandyopadhyay, K.K. Ghosh, P.K. Manoranjan Mohanty, (2004). Rice residue - management options and effects on soil properties and crop productivity. Journal of Food, Agriculture and Environment. 2,1, 224-231. 
Misra, R.V. (2011). Sri Lanka. Case studies on policies and strategies for sustainable soil fertility and fertilizer management in south Asia. Regional office for Asia and the pacific, FAO, 121-116.

Mohammad, S.I. (2010). Effect of integrated nutrient management on yield and nutrient use efficiency of rice-rice cropping system. Ph.D. Thesis Bangandhu skeikh Mujibur Rahaman Agricultural University, Gsipur.

Panabokke, C.R. (1996). Soil and agro-ecological environment in Sri Lanka. Natural Resources, Energy and Science Authority of Sri Lanka, 37-40.

Siavoshi, M. Nasiri, A. and Laware, S.L. (2011). Effect of Organic Fertilizer on Growth and Yield Components in Rice (Oryza sativa L.). Journal of Agricultural Science. 3, 3, 217- 224.

Venkatewaralu, B. and Vispears, R.M. (1987). Solar radiation and rice productivity. IRRI research paper series, 129, IRRI, Manila, Philipines, 22 p.

Weerahewa, J. Kodithuwakku, S. S. and Ariyawardana, A. (2010). Case study No. 7- 11. pp. 7. In: Andersen, P. and Fuzhi Cheng (Ed.) "Food policy for developing countries: the role of government in the global food system 2010", Cornell University, Ithaca, New York.

Wickramasinghe, W.M.A.D.B. and Wijewardena, J.D.H. (2003). Soil fertility management and integrated nutrition management system in rice cultivation, Rice congress 2000, 125-141. 